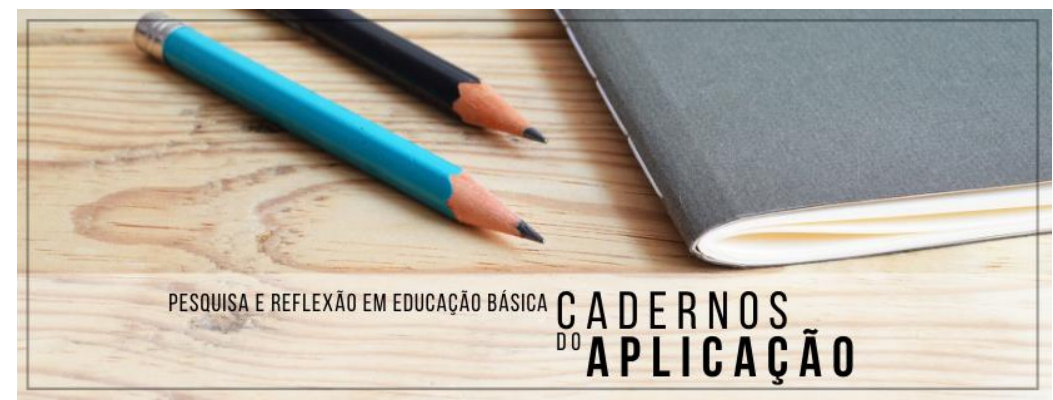

Cadernos do Aplicação

https://seer.ufrgs.br/CadernosdoAplicacao

Publicação Ahead of Print

ISSN 2595-4377 (online)

Porto Alegre | jul-dez. 2021 | v.34 | n.2

\title{
Processos de inclusão/exclusão: percepções sobre a Educação Física escolar na educação infantil
}

\author{
Michele Pereira de Souza da Fonseca ${ }^{1}$ \\ Luiza Fagundes Cardozo ${ }^{2}$
}

\begin{abstract}
Resumo: $O$ estudo tem como objetivo analisar as situações de ensino e seus processos de inclusãolexclusão observados nas aulas de Educação Física na educação infantil numa escola pública na periferia da cidade do Rio de Janeiro. Apoiamo-nos num conceito de inclusão processual, dialético e infindável (SAWAIA, 2017; BOOTH e AINSCOW, 2011; SANTOS, FONSECA e MELO, 2009), considerando amplamente todas as singularidades humanas. É um estudo de caso, com abordagem qualitativa, cujos participantes pesquisados foram a professora de Educação Física e os 60 estudantes de turmas de Pré Escolar I e II. Cinco categorias (competição, gênero, relações étnico-raciais, violência e não participação) emergiram após a observação das aulas, evidenciando que situações excludentes precisam ser problematizadas para que os estudantes entendam o sentido da sua participação e a importância da construção da sua identidade como cidadão protagonista, desde a educação infantil. $O$ ambiente escolar precisa ser um lugar acolhedor e inclusivo, onde as/os estudantes tenham suas diferenças reconhecidas e valorizadas, sejam elas de gênero, classe social, religiosidade, relações étnico raciais, deficiência, entre outras.
\end{abstract}

Palavras-chave: Educação Física escolar. Processos de inclusãolexclusão. Educação infantil.

\section{Inclusion/exclusion processes: perceptions about physical education at school in early childhood education}

\begin{abstract}
The study aims to analyze the teaching situations and their inclusion/exclusion processes observed in Physical Education classes in early childhood education in a public school on the outskirts of the city of Rio de Janeiro. We rely on a concept of procedural, dialectical and endless inclusion (SAWAIA, 2017; BOOTH \& AINSCOW, 2011; SANTOS, FONSECA \& MELO, 2009), considering all human singularities. It is a case study, with a qualitative approach, whose researched participants were

\footnotetext{
${ }^{1}$ Doutora em Educação (PPGE/UFRJ), Mestre em Educação (PPGE/UFRJ), Licenciada em Educação Física (EEFD/UFRJ). Professora adjunta da Escola de Educação Física e Desportos da Universidade Federal do Rio de Janeiro (EEFD/UFRJ). Coordenadora do LEPIDEFE - Laboratório de Estudos e Pesquisas sobre Inclusão e Diferenças na Educação Física Escolar (EEFD/UFRJ). E-mail: michelepsf22@gmail.com . ORCID iD: https://orcid.org/0000-0003-0355-2524

2 Pós-graduada em Educação Física Escolar na Perspectiva Inclusiva (EEFDUFRJ). Licenciada em Educação Física (EEFD/UFRJ). Graduanda em Educação Física (Bacharelado) (EEFD/UFRJ). Graduanda em Pedagogia pelo Centro Universitário UNIFACVEST. Integrante do Laboratório de Estudos e Pesquisas sobre Inclusão e Diferenças na Educação Física Escolar (LEPIDEFE) vinculado à EEFD/UFRJ. E-mail: luizafagundesc@gmail.com. ORCID iD: https://orcid.org/0000-0001-8658-5748
} 


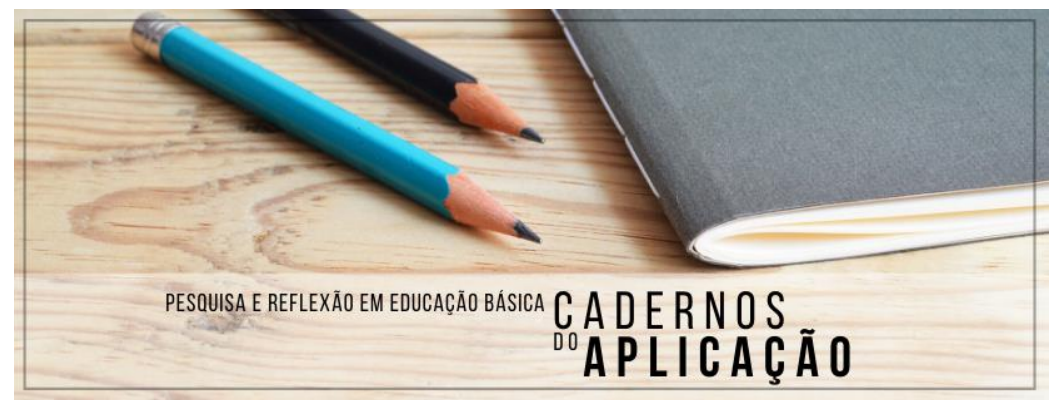

Cadernos do Aplicação

https://seer.ufrgs.br/CadernosdoAplicacao

Publicação Ahead of Print

ISSN 2595-4377 (online)

Porto Alegre | jul-dez. 2021 | v.34 | n.2

the Physical Education teacher and the 60 students from Pre-School classes I and II. Five categories (competition, gender, ethnic racial relations, violence and non participation) emerged after observing the classes, showing that excluding situations need to be problematized so that students understand the meaning of their participation and the importance of building their own identity as a protagonist citizen, since early childhood education. The school environment needs to be a welcoming and inclusive place, where students have their differences recognized and valued, whether in terms of gender, social class, religiosity, ethnic racial relations, disability, and others.

Keywords: School Physical Education. Inclusion/exclusion processes. Early childhood education.

\title{
Procesos de inclusión/exclusión: percepciones sobre la educación física en la escuela en la educación de la primera infancia
}

\begin{abstract}
Resumen: El estudio tiene como objetivo analizar las situaciones docentes y sus procesos de inclusión/exclusión observados en las clases de educación física en la educación de la primera infancia en una escuela pública en las afueras de la ciudad de Río de Janeiro. Nos apoyamos en un concepto de inclusión procedimental, dialéctica e interminable (SAWAIA, 2017; BOOTH y AINSCOW, 2011; SANTOS, FONSECA y MELO, 2009), considerando todas las singularidades humanas. Se trata de un caso de estudio, con un enfoque cualitativo, cuyos sujetos participantes fueron el profesor de educación física y los 60 alumnos de las clases de preescolar I y II. Cinco categorías (competencia, género, relaciones étnico-raciales, violencia y no participación) surgieron después de la observación de las clases, evidenciando que las situaciones excluyentes deben ser problematizadas para que los estudiantes entiendan el significado de su participación y la importancia de construir su identidad como ciudadano protagonista, desde la primera infância. El ambiente escolar debe ser un lugar acogedor e inclusivo, donde los estudiantes tengan sus diferencias reconocidas y valoradas, ya sea en términos de género, clase social, religiosidad, relaciones étnicas raciales, discapacidad, entre otros.
\end{abstract}

Palabras clave: Educación Física escolar. Procesos de inclusión/exclusión. Educación infantil.

\section{Introdução}

Reconhecida na Constituição da República Federativa do Brasil (BRASIL, 1988) como um direito social, a educação se configura como um grande desafio atualmente. A busca incessante por uma educação de qualidade, inclusiva, crítica e democrática para todas as pessoas é uma luta que deve ser coletiva e priorizada constantemente.

Quando defendemos a educação como direito de todos, nos referimos a uma educação de fato inclusiva que atenda a toda e qualquer pessoa considerando suas necessidades educacionais específicas, sejam elas permanentes ou temporárias. Partindo dessa preocupação 


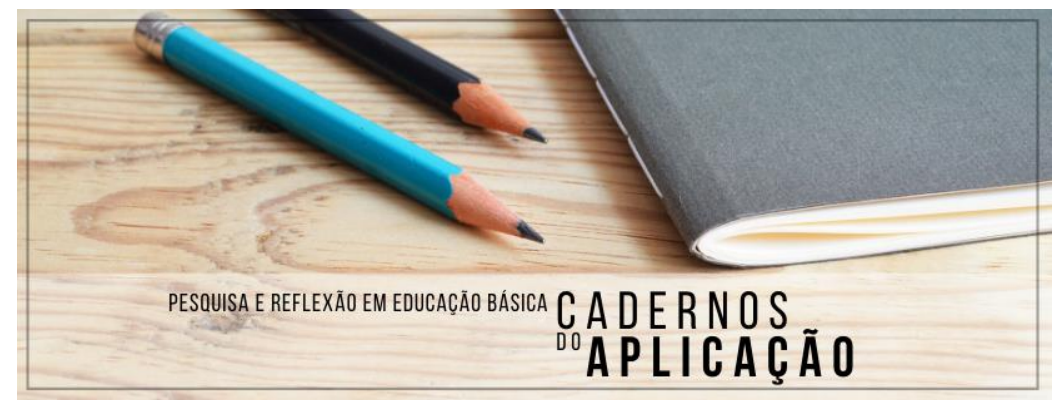

Cadernos do Aplicação

https://seer.ufrgs.br/CadernosdoAplicacao

Publicação Ahead of Print

ISSN 2595-4377 (online)

Porto Alegre | jul-dez. 2021 | v.34 | n.2

mais ampla, abordaremos neste artigo questões inquietantes que se apresentam na Educação Física na educação infantil, considerando processos inclusivos/excludentes.

Mesmo considerando que historicamente a inclusão é mais vinculada às questões envolvendo a deficiência, nosso referencial teórico é abrangente, pois nos apoiamos num conceito de inclusão processual, dialético e infindável (SAWAIA, 2017; BOOTH e AINSCOW, 2011, SANTOS, FONSECA e MELO, 2009), considerando amplamente todas as singularidades humanas em seus processos de inclusão/exclusão como questões de gênero, relações étnico-raciais, classe social, religiosidade, deficiências e outras tantas.

Apesar das políticas que partiram de nações hegemônicas expressarem também interesses particularistas e do capitalismo (FONSECA, 2014), a Declaração Mundial sobre Educação para Todos (UNESCO, 1990) e a Declaração de Salamanca (UNESCO, 1994) são marcos documentais dessa perspectiva mais ampla de inclusão em prol da luta pelos direitos dos cidadãos à educação.

A Declaração Mundial sobre Educação para Todos, elaborada a partir da Conferência Mundial de Educação para Todos, realizada em 1990, em Jomtien, na Tailândia, reafirma a educação como direito de todas as pessoas, não guetizando nenhum grupo, baseando-se em princípios democráticos e humanistas cujas principais propostas eram de aumento na quantidade de crianças e adolescentes frequentando a escola, providências que assegurassem a permanência desses estudantes na escola e reformas educacionais que promovessem maiores oportunidades e que efetivamente correspondessem às necessidades dos estudantes, famílias e comunidades locais.

A Declaração de Salamanca, elaborada a partir da Conferência Mundial de Educação Especial, em 1994, ampliou o conceito de pessoas com necessidades educacionais especiais, considerando especificidades importantes de não serem invisibilizadas, afirmando a escola inclusiva como um princípio fundamental de que todas as crianças devem aprender juntas e assegurando uma educação de qualidade a todos. Sobre a citada declaração: 


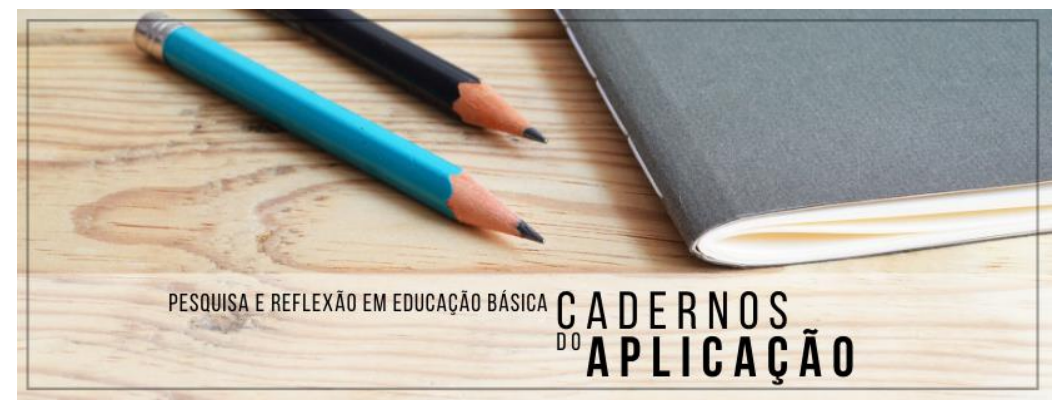

Cadernos do Aplicação

https://seer.ufrgs.br/CadernosdoAplicacao

Publicação Ahead of Print

ISSN 2595-4377 (online)

Porto Alegre | jul-dez. 2021 | v.34 | n.2

[...] o conceito de necessidades educacionais especiais passou a incluir, além das crianças portadoras ${ }^{3}$ de deficiência, aquelas que estejam experimentando dificuldades temporárias ou permanentes na escola, as que estejam repetindo continuamente $\mathrm{o}$ ano escolar, as que sejam forçadas a trabalhar, as que vivem nas ruas ou que moram distantes de qualquer escola, as que vivem em condições de extrema pobreza ou que sejam desnutridas, as que sejam vítimas de guerras e conflitos armados, as que sofrem de abusos contínuos físicos, emocionais e sexuais, ou as que estão fora da escola, por qualquer motivo que seja. (SANTOS, 2000, p.5)

A partir disso, é significativo o avanço, especificamente em relação às legislações nacionais sobre os direitos das pessoas público-alvo da educação especial (pessoas com deficiência, transtorno do espectro autista e com superdotação/altas habilidades), como evidenciado na Política Nacional de Educação Especial na perspectiva da Educação Inclusiva (BRASIL, 2008) e na Lei Brasileira de Inclusão (BRASIL, 2015), embora ainda existam problemas na efetivação dessas políticas no cotidiano escolar, muito em decorrência de problemas estruturais do sistema brasileiro de educação.

Paulo Freire (1987, p.37) há muito já questionava um modelo educacional diretivo, calcado somente na transmissão passiva do conhecimento, o que denominou de educação bancária, considerando que "a educação se torna um ato de depositar, em que os educandos são os depositários e o educador o depositante". Ao depositar o conhecimento, como se fosse atender a um padrão único de estudante sem problematizar as especificidades, as necessidades e o contexto de cada um, distancia-se da concepção de inclusão que embasa este artigo (SAWAIA, 2017; BOOTH e AINSCOW, 2011; SANTOS, FONSECA e MELO, 2009), aprofundando a exclusão e a desvalorização, seja por causa de orientação sexual, credo, estrutura familiar, deficiência, estilo de vida, classe econômica, gênero, etnia ou qualquer singularidade. Dessa forma, objetiva-se uma educação inclusiva, centrada no respeito, no reconhecimento e valorização das diferenças, possibilitando o desenvolvimento, a autonomia intelectual, social e humanização dos estudantes. Para que isso ocorra, o cenário escolar e a formação docente precisam ser repensados.

\footnotetext{
3 A terminologia "portador de deficiência" não é mais adequada, atualmente recomenda-se usar "pessoa com deficiência". De acordo com Friche, Araújo, Reis e Bonolo (2015, p.13): "O termo "portador" implica em algo que se "porta", que é possível se desvencilhar quando se deseja. Pode remeter a algo que é temporário, sendo que a deficiência na maioria das vezes é permanente. Além disso, ao utilizarmos esse termo estamos rotulando as pessoas e não valorizando, necessariamente, sua condição humana."
} 


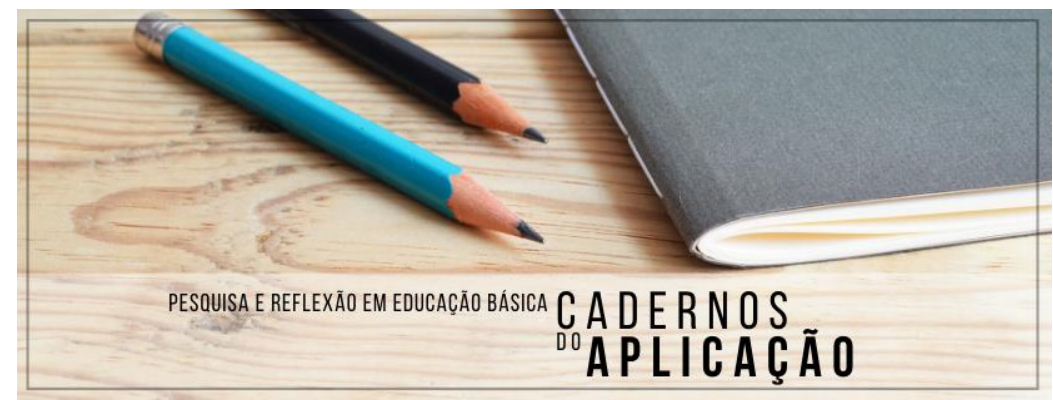

Cadernos do Aplicação

https://seer.ufrgs.br/CadernosdoAplicacao

Publicação Ahead of Print

ISSN 2595-4377 (online)

Porto Alegre | jul-dez. 2021 | v.34 | n.2

São evidentes as lacunas existentes entre o que está na legislação e a realidade que é vivenciada todos os dias. O sistema educacional brasileiro é segregativo e falho. Ainda existe um enorme despreparo por parte das escolas em perceber e reconhecer a diferença como uma vantagem pedagógica, como aponta a educadora Emilia Ferreiro citada por Lerner (2007), e isso abrange aspectos arquitetônicos, pedagógicos e sociais, o que dificulta o ingresso e permanência com qualidade desses estudantes.

Tardif (2008) e Imbernón (2011) problematizam sobre lacunas na formação inicial, despreparo docente, relações humanas, metodologias de ensino, identidade e saberes docentes. Nesse sentido, apontamos algumas inquietações envolvendo docentes, funcionários, mediadores e diretores desamparados para atender os estudantes, a culpabilização dos mesmos pelo despreparo, a falta de suporte ou materiais adaptados para que os estudantes possam participar ativamente das aulas, a inexistência ou limitação de acessibilidade no cenário escolar, a ausência de acolhimento para diferentes culturas, crenças e opiniões, o preconceito por parte da comunidade escolar e a carência de atendimento especializado e singularizado.

Os problemas contemporâneos da educação brasileira são imensos, porém, entendemos que não podem ser analisados de maneira reducionista somente considerando a educação em si, destacada das complexidades da sociedade.

Longe de entender a educação como determinante principal das transformações sociais, reconhece ser ela elemento secundário e determinado. [...] entende que a educação se relaciona dialeticamente com a sociedade. Nesse sentido, ainda que elemento determinado, não deixa de influenciar o elemento determinante. Ainda que secundário, nem por isso deixa de ser instrumento importante e por vezes decisivo no processo de transformação da sociedade. (SAVIANI, 2011, p. 75)

Os desafios emergentes demandam debates, produção de conhecimentos, propostas e ações para atender tais questões tão complexas. Assim, é fundamental dar às crianças, jovens e adultos a possibilidade de aprender a colaborar, ter autonomia, ser valorizado por suas pequenas ou grandes conquistas e ter liberdade de se expressar autonomamente. Como é abordado na Declaração de Salamanca: 


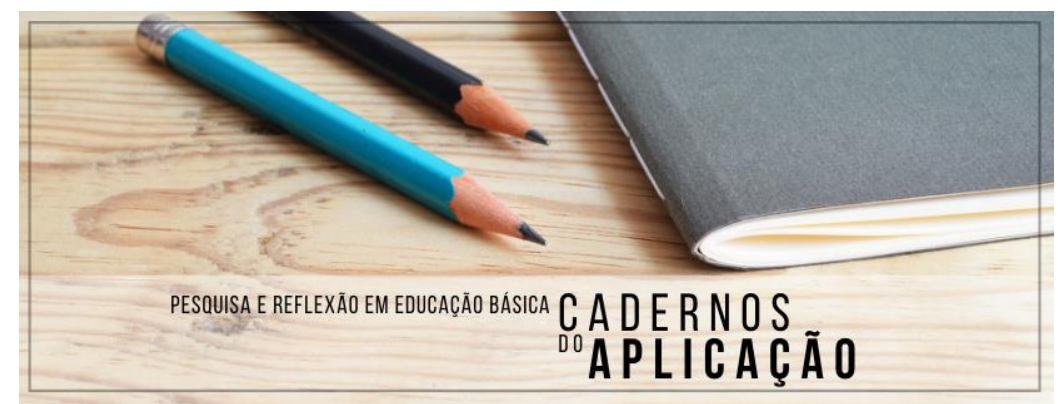

Cadernos do Aplicação

https://seer.ufrgs.br/CadernosdoAplicacao

Publicação Ahead of Print

ISSN 2595-4377 (online)

Porto Alegre | jul-dez. 2021 | v.34 | n.2

Toda criança possui características, interesses, habilidades e necessidades de aprendizagem únicas. Sistemas e programas educacionais devem ser designados e implantados para contemplar a ampla diversidade dessas características e necessidades. (UNESCO, 1994, p.01)

O Coletivo de Autores (1992, p.13) conceitua Educação Física como "prática pedagógica que no contexto escolar tematiza formas de atividades expressivas corporais entre elas o jogo, o esporte, a dança, a ginástica, formas que configuram uma área de conhecimentos que denominam de "cultura corporal'”. A Educação Física escolar, como componente curricular obrigatório da educação básica (BRASIL, 1996), pode ter um papel fundamental na busca por uma abordagem inclusiva, no qual a escola precisa propiciar aos estudantes meios para reconhecer e atender às diferenças, e assim favorecer as trocas profícuas entre ensinar e aprender. Há grande potência para propiciar o desenvolvimento global dos estudantes, facilitar o processo de inclusão e aceitação em seu grupo social e incentivar a valorização e respeito às diferentes maneiras de ser e estar no mundo. Isso, desde que cumpra seu papel social dentro das perspectivas pedagógicas inclusivas na escola.

Desta forma, o presente estudo tem como objetivo analisar as situações de ensino e seus processos de inclusão/exclusão observadas nas aulas de Educação Física na educação infantil numa escola pública na periferia da cidade do Rio de Janeiro.

A educação infantil, prevista na educação brasileira desde a Constituição de 1988 (BRASIL, 1988), se constitui, segundo a Lei de Diretrizes e Bases da Educação Nacional, artigo 29, como:

primeira etapa da Educação Básica, tem como finalidade o desenvolvimento integral da criança até os 5 (cinco) anos, em seus aspectos físico, psicológico, intelectual e social, complementando a ação da família e comunidade (BRASIL, 1996).

Especificamente com relação à Educação Física, Sayão (1996, 1997, 1999, 2002), em diversos estudos sobre a educação infantil desde a década de 1990, já apontava a necessidade de construção de um projeto educativo que superasse a fragmentação corpo-mente, sala-pátio e teoria-prática. A citada autora, tendo a teoria de Vygotsky como suporte, criticava a linearidade de padrões no que tange aos processos de aprendizagem e desenvolvimento infantil e seus reflexos na prática da Educação Física na educação infantil. 
Nesse sentido, é de grande importância que a Educação Física escolar na educação infantil, assumindo atuar na perspectiva inclusiva, apresente aos estudantes diferentes culturas e perspectivas e assim, diminua as práticas e conceitos competitivos e excludentes precocemente já transmitidos na infância. Percebemos, assim, o quanto é necessário criar reflexões acerca da inclusão na Educação Física escolar e apontar as lacunas existentes entre os discursos e ações que envolvem as necessidades educacionais específicas de cada estudante.

Considerando isso, é possível buscarmos caminhos que contemplem uma Educação Física escolar, na qual seja atendido todo e qualquer estudante reconhecendo e valorizando suas diferenças e que promovam experiências educacionais significativas em uma formação reflexiva para todos/as, mesmo voltada para a educação infantil, guardadas as devidas adequações e especificidades. Esta busca está em consonância com o que é apresentado na Base Nacional Comum Curricular - BNCC (BRASIL, 2018, p.38), considerando como um dos direitos de aprendizagem e desenvolvimento na educação infantil "expressar, como sujeito dialógico, criativo e sensível, suas necessidades, emoções, sentimentos, dúvidas, hipóteses, descobertas, opiniões, questionamentos, por meio de diferentes linguagens."

A Educação Física tem marcas de uma história excludente com reflexos em toda Educação Básica e na formação docente. Há avanços em termos do discurso, propondo mudanças referentes ao sentido e ao significado de como deve ser abordada na escola. Percebese, então, transformações nas abordagens pedagógicas na Educação Física escolar, alusivas ao olhar educacional sobre a inclusão das diferenças, entretanto, as perspectivas militaristas e competitivistas, bem como a ênfase na técnica e na habilidade física, ainda são muito presentes nas práticas escolares. (SILVA, 2004, FONSECA, 2014).

Farias et al (2019, p. 2) afirmam, apoiados em estudos de Sayão (1999; 2002) que historicamente a formação inicial em Educação Física tem negligenciado as demandas específicas de crianças nessa faixa etária, considerando "que os conteúdos, os tempos e os espaços, muitas vezes, fogem da lógica de atendimento das demais etapas da educação básica”.

O esporte e a competitividade ainda são utilizados majoritariamente na escola, em que são valorizados os mais habilidosos, os mais velozes, os mais altos, os mais talentosos; e os que fogem desses padrões são esquecidos e considerados fracassos. O Coletivo de Autores (1992) desde a década de 1990, já problematizava sobre o esporte e a ênfase exacerbada nos elementos 


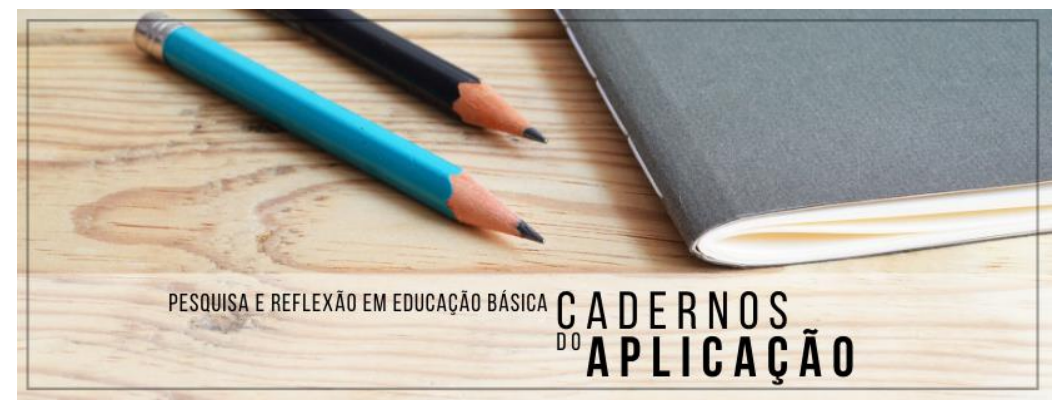

Cadernos do Aplicação

https://seer.ufrgs.br/CadernosdoAplicacao

Publicação Ahead of Print

ISSN 2595-4377 (online)

Porto Alegre | jul-dez. 2021 | v.34 | n.2

técnico-táticos, bem como na vitória da competição resumindo-se como fim em si mesmo. Esta ainda é uma questão atual na Educação Física escolar como um todo, e que acaba atingindo também a educação infantil.

A partir do surgimento das abordagens pedagógicas contemporâneas na Educação Física, as práticas homogeneizadoras e excludentes começaram a ser questionadas. Com isso, pretende-se que haja uma preocupação com as singularidades dos estudantes contemplando a diversidade social, cultural e étnica existente. Amplas possibilidades e estratégias existem para considerar as particularidades dos estudantes no ambiente escolar quando a formação integral é empregada em detrimento ao rendimento técnico.

A disciplina Educação Física tem uma peculiaridade com relação às outras disciplinas escolares, pois é permitida uma grande flexibilidade na seleção de conteúdos, ou seja, é possível trabalhar uma amplitude de ações, com variações, adaptações e aplicações diversas. É possível que o professor planeje estratégias, desconstrua ideias tradicionais e trilhe vários caminhos diferentes para se chegar a um objetivo (FONSECA e RAMOS, 2017, p. 194).

As autoras citadas acima ressaltam a importância da diversificação de conteúdos para atender as variadas singularidades e possibilidades dos estudantes, ampliando o conceito de participação, considerando "a real possibilidade motora do aluno, as atitudes e intenções demonstradas por ele, bem como os conhecimentos trazidos, refletidos e ressignificados por ele durante a aula" (p.197), se distanciando, assim, da ideia fixa de que "todos devem produzir exatamente os mesmos gestos para o sucesso da atividade"(FONSECA e RAMOS, 2017, p.197).

Dessa forma, nos aproximamos da perspectiva inclusiva de modo a atender as diferentes demandas das aulas, questionar a realidade social em cada contexto escolar, problematizar e refletir sobre a cultura corporal, possibilitando, por meio de diferentes expressões corporais, externalizar o que tem dificuldade de verbalizar, desconstruir ações socialmente reforçadas, conquistar autonomia e estruturar-se como cidadão crítico e participativo.

Farias et al (2019, p.9) apontam, a partir de uma análise da produção de dissertações e teses sobre a Educação Física na educação infantil, que um número expressivo de estudos têm tratado "aspectos do desenvolvimento motor, aprendizagem motora, testes de aptidão física, nível de atividade física, análise psicomotora e validação de testes". 


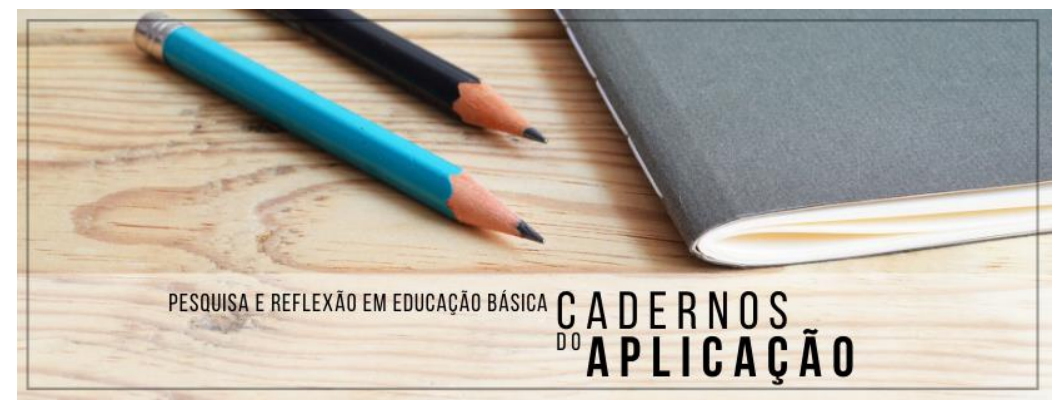

Cadernos do Aplicação

https://seer.ufrgs.br/CadernosdoAplicacao

Publicação Ahead of Print

ISSN 2595-4377 (online)

Porto Alegre | jul-dez. 2021 | v.34 | n.2

Esse achado já foi encontrado no levantamento de Picelli (2002) e é reforçado no trabalho de Assis (2015), nos quais as atuações da EF na EI têm um predomínio voltado para as perspectivas psicomotoras, baseados no desenvolvimento adequado por faixas etárias das crianças, e muitas vezes vêm relacionadas à alfabetização. Nesse tipo de perspectiva, o entendimento de sujeito que se constitui como ser social, histórico e cultural é desconsiderado (ASSIS, 2015). (FARIAS et al, 2019, p.10)

Considerando a grande possibilidade de inserção da Educação Física nos cinco campos de experiências previstos na BNCC da educação infantil (o eu, o outro e o nós; corpo, gestos e movimentos; traços, sons, cores e formas; escuta, fala, pensamento e imaginação; espaços, tempos, quantidades, relações e transformações), é necessária profunda reflexão sobre a histórica influência competitiva e não reflexiva na Educação Física, para não tornar as aulas na educação infantil um compilado de movimentos padronizados e mecânicos.

Como destacado por Fonseca (2014, p.61), contemporaneamente, [...] "busca-se valorizar e reconhecer as diferenças, não as identificando como obstáculos e sim como desafios, como recursos que podem enriquecer as relações humanas e promover ações transformadoras na Educação Física escolar". Isto posto, este estudo visa problematizar os processos de inclusão/exclusão nas aulas de Educação Física na educação infantil, intencionando contribuir para reflexões nesse campo.

\section{Métodos}

Segundo Lüdorf (2004, p. 47), de acordo com a intenção do estudo em um projeto, a pesquisa pode ser teórica ou teórico-empírica. A pesquisa aqui apresentada é teórico-empírica, ou seja, "quando além da pesquisa bibliográfica, é realizado um trabalho de campo, algum tipo de coleta de dados."

De acordo com a abordagem utilizada, esta pesquisa é de caráter qualitativo, pois se importa com a realidade das experiências observadas e não em transformá-las em dados quantitativos; é centrada em compreender e explicar o processo das relações sociais (GERHARDT e SILVEIRA, 2009). 


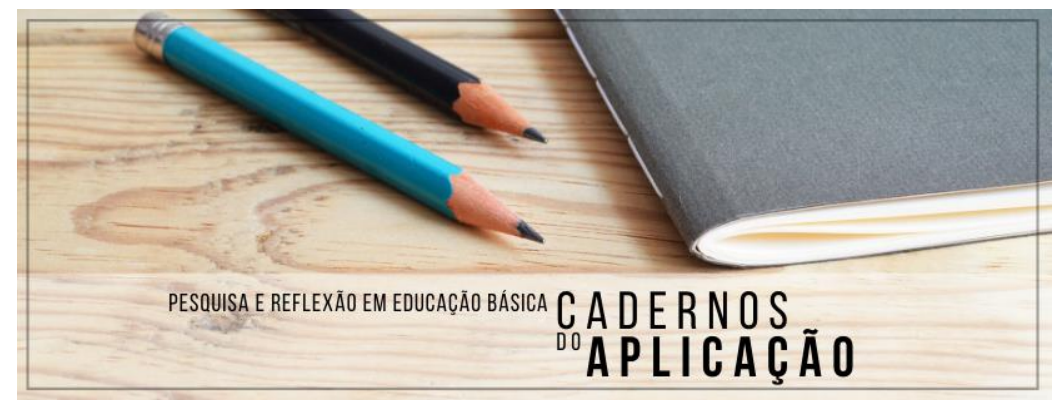

Cadernos do Aplicação

https://seer.ufrgs.br/CadernosdoAplicacao

Publicação Ahead of Print

ISSN 2595-4377 (online)

Porto Alegre | jul-dez. 2021 | v.34 | n.2

Realizada numa Escola Municipal de educação infantil (recentemente denominada de Espaço de Desenvolvimento Infantil - EDI) na Zona Oeste do Rio de Janeiro, é um estudo de caso pois, como definido a seguir:

Pode ser caracterizado como um estudo de uma entidade bem definida como um programa, uma instituição, um sistema educativo, uma pessoa, ou uma unidade social. Visa conhecer em profundidade o como e o porquê de uma determinada situação que se supõe ser única em muitos aspectos, procurando descobrir o que há nela de mais essencial e característico. O pesquisador não pretende intervir sobre o objeto a ser estudado, mas revelá-lo tal como ele o percebe. (FONSECA, 2002, p. 33)

Os instrumentos de coleta de dados foram a observação das turmas e entrevista, além disso, todas as situações observadas foram registradas num diário de campo. A observação consiste em coletar dados reais de determinado grupo social para examinar, analisar informações e dar sentido a elas (LAKATOS e MARCONI, 2003).

Por meio da observação, realizada durante 20 aulas de Educação Física na educação infantil, registramos no diário de campo situações envolvendo professora/alunos e aluno/aluno, durante as aulas de uma turma de pré-escola I e duas turmas de pré-escola II com média de 20 alunos por turma.

A professora estava ciente e concordou em participar da pesquisa, assinando o termo de consentimento livre e esclarecido, atendendo aos princípios éticos da pesquisa. Por meio de um roteiro padronizado e estruturado, validado por dois pesquisadores da área, a intenção da entrevista foi obter informações da entrevistada. Realizada com a professora, a entrevista continha 7 perguntas sobre sua formação e aspectos sobre a inclusão em educação/Educação Física.

Para discussão dos dados foi utilizada a metodologia de análise de conteúdo para definir e organizá-los. Para Bardin:

Um conjunto de técnicas de análise das comunicações visando obter, por procedimentos sistemáticos e objetivos de descrição do conteúdo das mensagens (quantitativos ou não) que permitam a inferência de conhecimentos relativos às condições de produção/recepção (variáveis inferidas) destas mensagens. (BARDIN, 2016, p.42) 


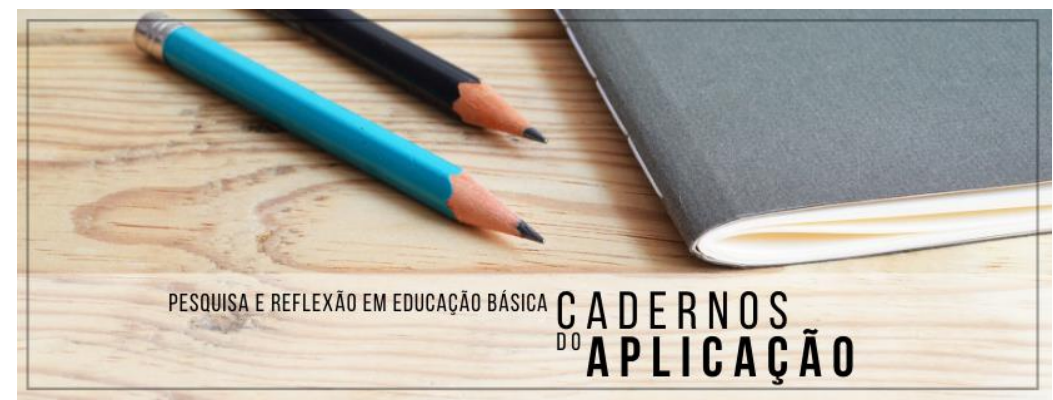

Cadernos do Aplicação

https://seer.ufrgs.br/CadernosdoAplicacao

Publicação Ahead of Print

ISSN 2595-4377 (online)

Porto Alegre | jul-dez. 2021 | v.34 | n.2

A análise de conteúdo acontece por meio da categorização, processo este, em que são reunidos vários fatos para serem transformados e organizados em diferentes categorias. Nele, as informações são caracterizadas e agrupadas ordenadamente para um melhor entendimento (BARDIN, 2016).

Elencamos cinco categorias, que segundo Bardin (2016) são consideradas pósdefinidas, porque emergiram após a coleta de dados. São elas: competição, gênero, relações étnico-raciais, violência e não participação.

\section{Resultados e discussão}

A análise dos dados é composta de duas partes: a entrevista com a professora de Educação Física e a discussão sobre as situações observadas. A professora entrevistada e que participou como sujeito ativo pesquisado neste estudo, tem 42 anos, possui 18 anos de formação em Licenciatura Plena em Educação Física em uma instituição privada de ensino, com PósGraduação em Psicomotricidade na Escola. Atua como professora na rede municipal do Rio de Janeiro desde 2003.

Com relação ao conceito de inclusão, a professora entende que significa atender a todas as crianças sem discriminação e adaptando as atividades para que elas participem de forma igualitária. Este depoimento está em consonância com o conceito de inclusão (SAWAIA, 2017; BOOTH e AINSCOW, 2011) referenciado neste estudo, considerando que na perspectiva de inclusão em educação, a escola deve respeitar e valorizar as diferenças presentes no meio e ajustar-se às especificidades de todo e qualquer estudante. Ao menos, em nível do discurso, esta concepção aproxima-se do referencial teórico que respalda este estudo.

A professora afirmou ainda que, em sua formação, cursou disciplinas diretamente voltadas à temática inclusão, mas não se lembra quais. Segundo ela, nas disciplinas que fez durante o curso de Educação Física, as aulas práticas e teóricas eram inclusivas, ou seja, de acordo com o relato da professora sua formação teve um caráter inclusivo.

Importa ressaltar que, corroborando Fonseca (2014), nenhuma formação é suficiente em si mesmo para preparar definitivamente um professor para lidar com quaisquer situações, especialmente no que tange a perspectiva inclusiva. A autora reforça que: 


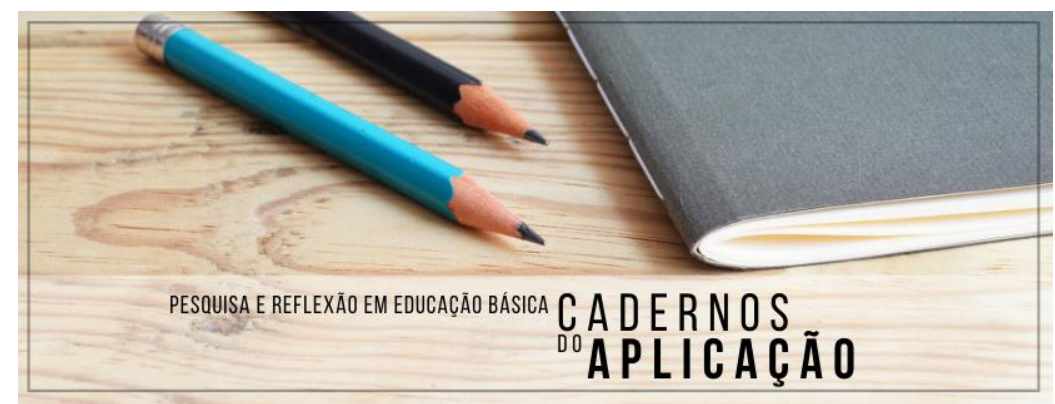

Cadernos do Aplicação

https://seer.ufrgs.br/CadernosdoAplicacao

Publicação Ahead of Print

ISSN 2595-4377 (online)

Porto Alegre | jul-dez. 2021 | v.34 | n.2

Obviamente não estaremos preparados do sentido estático do termo e sim, processualmente nos preparando à medida que as situações emerjam. Falo de preparo não como uma preparação prévia técnica-metodológica para o trato das diversidades e sim, um preparo atitudinal, crítico, cidadão, investigativo e criativo (FONSECA, 2014, p.64).

Ao discorrer sobre a sua prática docente, a professora assegurou que tem o cuidado de planejar suas aulas considerando a preocupação de serem atividades inclusivas e também afirmou categoricamente que em suas aulas não há situações excludentes.

Após todo o período de observação das aulas nas três turmas, foram elencadas cinco categorias para apresentar e discutir as situações observadas, apoiadas nas anotações no diário de campo.

Na categoria "competição" relacionamos as duas situações. Na situação 1, a atividade foi a "Coelho sai da toca". Nela, cada estudante deveria entrar em uma "toca" e à medida que os arcos eram retirados a cada rodada, o estudante que ficasse sem "toca" deveria sair da brincadeira. Ao final sempre existia um único vencedor e isso era enfatizado pela professora. Em um momento após não ter conseguido entrar em uma "toca", um estudante ficou excluído da atividade e muito insatisfeito, chutou a parede do pátio. A professora não interveio.

$\mathrm{Na}$ situação 2, a atividade observada foi a "Galinha choca". O estudante que era queimado por outro com a bola deveria sentar-se no centro do círculo como se estivesse "chocando" o ovo. Só poderia sair de lá e voltar para a brincadeira quando houvesse um novo aluno "perdedor". Algumas crianças que eram escolhidas por último para ser o pegador ficavam chateados e reclamando, nesse caso também a professora não interveio.

Dialogando com o referencial teórico, percebemos a influência de uma Educação Física de cunho muito excludente e competitivo voltada para a performance, onde a prática não reflexiva (prática pela prática) está ainda muito viva nas aulas. Mesmo tendo avançado em termos de discurso, os casos 1 e 2 evidenciam o quão as práticas educacionais ainda continuam competitivas e excludentes.

[...] a cultura desportiva e competitiva, dominante nas propostas curriculares da Educação Física cria um obstáculo adicional à inclusão de alunos que são inicialmente encarados como menos capazes para um bom desempenho (por várias razões) numa competição (CHICON, 2008, p.30-31) 
Cadernos do Aplicação

https://seer.ufrgs.br/CadernosdoAplicacao

Publicação Ahead of Print

ISSN 2595-4377 (online)

PESQUisa e REFLEXão em EdUCAÇão básica $C$ A D E R N OS

${ }^{0} A P L I C A C ̧ A ̃ O$

Porto Alegre | jul-dez. 2021 | v.34 | n.2

É importante ressaltar que nas aulas da professora o esporte não é enfatizado, e sim são escolhidas temáticas lúdicas e brincadeiras populares, o que é mais adequado para a educação infantil. Embora ela tenha essa visão lúdica do que é apropriado para essa faixa etária, ainda está enraizada em suas práticas uma Educação Física voltada para a competição, que naturaliza a exclusão, distanciando-se da perspectiva inclusiva.

Chicon (2008, p.30) reforça esse argumento, ao questionar a formação nos cursos de Educação Física, que acaba por influenciar muitos professores a pouco problematizar essas exclusões presentes nas aulas e desenvolvem "posturas discriminadoras, uma vez que o trabalho estava voltado aos mais habilitados e talentosos". Essa postura não reflexiva dos professores precisa ser repensada, posto que, quem fica de fora têm menos chances de aprender e participar ativamente.

$\mathrm{Na}$ categoria "gênero" elencamos mais 4 situações: na situação 3, observou-se que durante diversas atividades a professora perguntava para a turma: "Quem vai ganhar: menino ou menina?", segundo ela para motivar os alunos, sempre colocando os dois grupos em disputa. Como de costume, nas aulas eram divididos em grupo de meninas e grupo de meninos. A professora também sempre incitava que os alunos gritassem "Vai perder!" para o grupo oposto e "Vai ganhar!" para o seu grupo. Diversas vezes as meninas reclamavam que durante algumas atividades era injusta a competição entre eles, por haver uma quantidade menor de meninas do que meninos.

Na situação 4, um dos alunos (menino) não quis que uma colega (menina) sentasse ao seu lado para assistir um desenho na sala de aula/vídeo, durante a aula de Educação Física num dia de chuva. Na situação 5, um aluno falou para o outro, que havia se machucado, que ele não deveria chorar porque é homem e homem não pode chorar. Em ambas as situações a professora não interferiu e/ou problematizou os fatos no momento ocorrido ou em outro posterior.

Em algumas aulas (situação 6), a professora oferecia materiais como bolas, cordas, cones e arcos para a turma brincar livremente como achasse melhor. Os alunos acabavam dividindo-se espontaneamente por gênero, a maioria dos meninos brincavam entre eles de chutar as bolas e as meninas com as cordas e os arcos. Em nenhum momento a professora questionava os alunos sobre essa segregação entre eles e o porquê de brincarem com materiais socialmente intitulados para meninos e para meninas. 


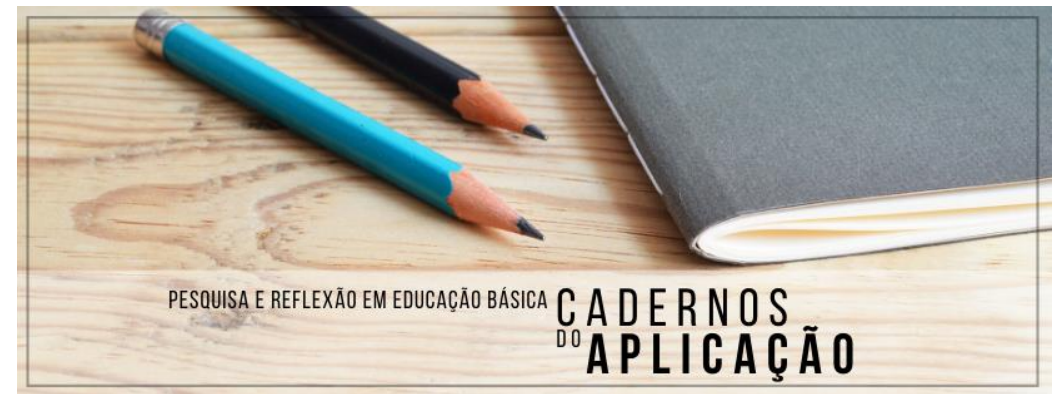

Cadernos do Aplicação https://seer.ufrgs.br/CadernosdoAplicacao

Publicação Ahead of Print

ISSN 2595-4377 (online)

Porto Alegre | jul-dez. 2021 | v.34 | n.2

As situações relatadas evidenciam o quanto a prática da professora reforça a superioridade masculina em relação à feminina. Mesmo com um número inferior de meninas para a realização de atividades, ela dividia a turma entre meninas e meninos, ao invés de separálos de maneira igualitária por meio de outros critérios que não fosse o de gênero. Isso reforça a competição e rivalidade entre os gêneros e não um trabalho conjunto para a desconstrução da imagem segregada que se impõe sobre o masculino e o feminino.

Sousa e Altmann afirmam:

[...] que na aparência das diferenças biológicas entre os sexos ocultaram-se relações de poder - marcadas pela dominação masculina - que mantiveram a separação e a hierarquização entre homens e mulheres, mesmo após a criação da escola mista, nas primeiras décadas deste século. Buscou-se manter a simbologia da mulher como um ser dotado de fragilidade e emoções, e do homem como força e razão, por meio das normas, dos objetos, do espaço físico e das técnicas do corpo e dos conteúdos de ensino, fossem eles a ginástica, os jogos ou - e sobretudo - os esportes. (SOUSA e ALTMANN, 1999, p.6)

Estas situações nos levam a refletir sobre o incentivo de disputas entre meninos e meninas, pois justamente reforça os estereótipos de gênero masculino de força e virilidade, e o feminino de delicadeza e inferioridade. Brito e Santos (2013, p. 243) apontam que "a categoria gênero, por muito tempo, não foi uma instância prioritária nas preocupações pedagógicas de professores/as e nos planejamentos escolares das aulas de Educação Física" e ainda ressaltam que:

A problematização das questões atuais de gênero, através do reconhecimento da existência de feminilidades e masculinidades entre alunos e alunas, mostrase essencial e indispensável nas práticas pedagógicas que buscam a inclusão e uma participação efetiva de meninos e meninas nas aulas de Educação Física (BRITO e SANTOS, 2013, p. 243)

Ao ignorar as situações que emergiram durante as aulas, a professora de alguma maneira silenciava o papel educacional que deve estar presente na escola em problematizar fatos que refletem a sociedade em que vivemos. Isso dificulta o rompimento com práticas naturalizadas e excludentes que perpetuam as desigualdades e reforçam a cultura machista e patriarcal nas aulas, na escola e na sociedade. 


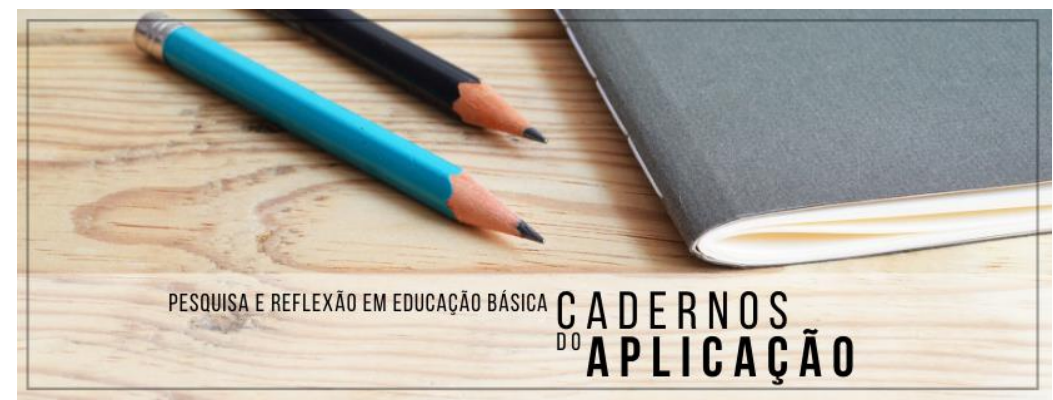

Cadernos do Aplicação

https://seer.ufrgs.br/CadernosdoAplicacao

Publicação Ahead of Print

ISSN 2595-4377 (online)

Porto Alegre | jul-dez. 2021 | v.34 | n.2

Especialmente nos últimos tempos, a palavra gênero vem carregada de interpretações equivocadas, porém, ao propor novas e diversas formas de divisão de grupo, optar por atividades que possam estar todos juntos na maioria das vezes em colaboração, diversificar os conteúdos para que experienciem outras práticas corporais, atentar ao discurso evitando falas carregadas de preconceito, já se constitui num terreno fértil para trabalhar questões de gênero Educação Física escolar.

$\mathrm{Na}$ categoria "relações étnico-raciais", as três situações aqui apresentadas giram em torno de um aluno, o Pedro ${ }^{4}$, um menino branco, de cabelo liso e com olhos azuis. Na situação 7, foi observado que as meninas da turma queriam sempre ficar perto, brincar e dar as mãos para ele. Durante uma conversa (situação 8) entre a professora de Educação Física e a professora regente da turma, elas disseram: "O Pedro é lindo, um príncipe, todo gentil e delicado. As meninas ficam doidas por ele."

Em outro momento (situação 9), durante a atividade cantada "A linda rosa juvenil", a professora chamou somente o Pedro para ser o rei. Seu papel era "despertar" com um toque a rosa que era uma menina e ficava "adormecida" no centro da roda, fato que entrecruza categorias e também reforça a cultura de submissão feminina. As práticas deveriam culminar no empoderamento das meninas e na desconstrução do estereótipo de subordinação aos homens, obviamente, conforme cabe na educação infantil.

Tais relatos retratam o quanto o preconceito ainda está presente. Santos e Silva (2018 p.256), dialogando com vários autores referência nesse campo, apontam que a partir da metade do século XIX, as teorias raciais baseavam-se no chamado racismo científico, afirmando "a ideia de que a humanidade está dividida em raças, e seu corolário, a saber, as diferentes raças conformam uma hierarquia biológica, na qual os brancos ocupam posição superior".

Ao escolher o Pedro por ser branco e ter olhos azuis para ser a referência como o príncipe, gentil e delicado, a professora reconheceu e reforçou o pensamento no qual a beleza europeia é dominante e valorizada, numa classe majoritariamente de corpos pretos e pardos. Nessa oportunidade, poderia ter valorizado a diversidade presente naquele contexto escolar, com diferentes tipos de corpos, cores e cabelos.

\footnotetext{
${ }^{4}$ Nome fictício para preservar a identidade do estudante em questão.
} 


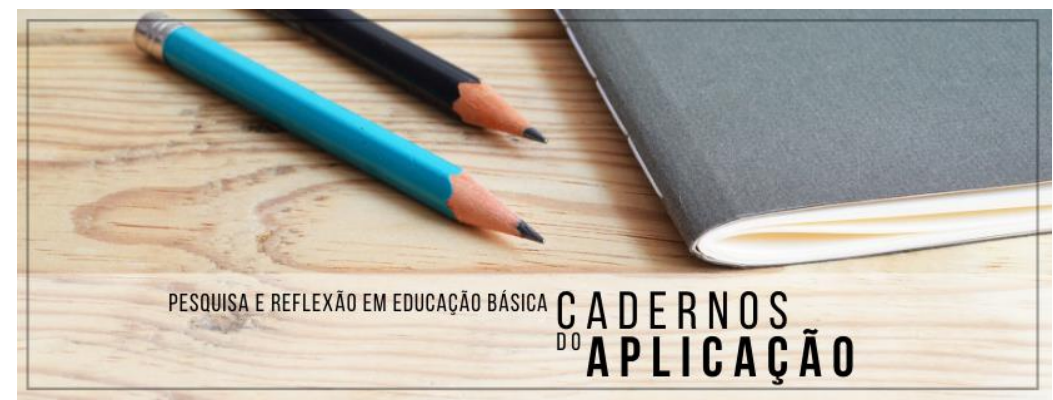

Cadernos do Aplicação

https://seer.ufrgs.br/CadernosdoAplicacao

Publicação Ahead of Print

ISSN 2595-4377 (online)

Porto Alegre | jul-dez. 2021 | v.34 | n.2

Podemos captar e compreender os mecanismos de funcionamento do ritual pedagógico que exclui, dos currículos escolares, a história de luta dos negros na sociedade brasileira; que impõe as crianças negras um ideal de ego branco; que produz um discurso sobre "o tratamento igual às crianças brancas e às não brancas"; que folcloriza a produção cultural da população negra. Esse ritual se legitima na instituição escolar, não por aquilo que é dito, mas por tudo aquilo que silencia. (GONÇALVES, 1987, p.27)

Especialmente nesses tempos em que casos de racismo são ainda muito frequentes, é importante que desde a educação infantil isso seja trabalhado em todas as oportunidades. A escola não pode omitir-se em problematizar questões sobre a valorização das singularidades de cada um e nem colocar uma única etnia como alvo preferencial e superior às outras.

Na categoria "violência", elencamos uma situação. No decorrer de uma atividade dentro da sala de aula (situação 10), um aluno falou que quando crescesse queria ser policial para poder andar armado. $\mathrm{O}$ fato passou despercebido e foi ignorado pela professora, que poderia, de forma leve criar estratégias para desenvolver o assunto, ou que, a partir daquele fato, pensasse em elaborar alguma atividade apresentando profissões e suas funções, de forma lúdica e criativa, por exemplo. Assim, poderia entender o motivo dessa fala e desmistificar a ideia da polícia associada à violência e ao uso de armas.

O diálogo com prática pedagógica cotidiana utilizada por eles(as) no enfrentamento das situações de violência no cotidiano escolar. Esses(as) professores(as) consideram que trabalhar o tema dentro da sala de aula através de debates ou atividades que propiciem o diálogo, envolver a criança conduzir atividades seu interesse e conquistar a confiança, o afeto e atenção dos(as) alunos(as) são estratégias que podem contribuir para minimizar o problema da violência. (CANDAU, LUCINDA e NASCIMENTO, 1999, p. 73)

Santos (2001) nos faz refletir sobre desencontros entre a instituição escolar e as particularidades culturais das populações pobres das grandes cidades. A escola, e especialmente a aula de Educação Física, pode ser um lugar onde são problematizadas questões sobre a violência, as necessidades mais precárias daquele contexto e a realidade dos estudantes naquela escola. Isso precisa ser considerado nas atividades, guardadas as devidas proporções da faixa etária, instaurando entre os colegas uma valorização do respeito e da não violência.

A categoria "não participação" foi composta de quatro situações. Na situação 11 , foi observado que um estudante foi para a aula de Educação Física com a sola de um dos tênis solta 


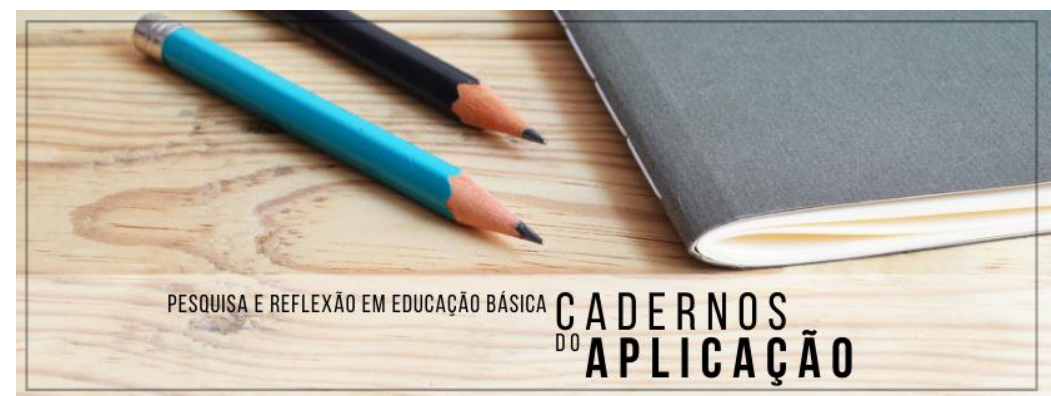

Cadernos do Aplicação

https://seer.ufrgs.br/CadernosdoAplicacao

Publicação Ahead of Print

ISSN 2595-4377 (online)

Porto Alegre | jul-dez. 2021 | v.34 | n.2

e quando a professora percebeu, ordenou que ele ficasse sentado sozinho enquanto o resto da turma fazia a atividade proposta. A impossibilidade material de algum aluno não pode ser pressuposto para a exclusão dele em qualquer atividade. Vivemos em uma sociedade extremamente desigual em que essas insuficiências materiais são muito presentes, logo, essa questão social não pode absolutamente ser desconsiderada nas aulas. O cunho educacional da Educação Física precisa estar presente em cada situação cotidiana que apareça.

Na situação 12, durante a atividade "Mímica" a professora ordenou que o aluno que estava muito desobediente deixasse de participar da atividade e ficasse sentado isolado. Ao longo de algumas atividades (situação 13), em certos momentos existiam alunos que ficavam isolados no canto por não querer participar, contudo a professora ou outros alunos não tentavam incluí-los. Por fim, na situação 14 alguns alunos eram esquecidos de serem chamados pela professora na atividade "galinha choca" e reclamavam por isso.

O conceito de participação na Educação Física escolar precisa ser reconfigurado e valorizado, referente à presença física e produção dos estudantes em todos os momentos das aulas, dentro das suas possibilidades. Mesmo quando há um impedimento clínico, emocional ou social, por exemplo, para justificar a não participação, isso não significa que não possa ser encontrada outra função para desempenhar, ou outro modo de participar.

Além disso, a não participação não pode ser usada como punição a um ato indisciplinado quando não se convida o estudante a refletir sobre o que aconteceu naquele espaço escolar, de modo a repensar suas ações. Fonseca e Ramos (2017, p. 200) apontam que "é primordial considerar as atitudes desenvolvidas por esse aluno para consigo e para com o grupo. Dessa maneira, respeitamos suas possibilidades e garantimos o seu direito legal de participar da aula de Educação Física na escola”.

Diversos estudos de Sayão, já citados neste artigo, enfatizam a importância de reconhecer a singularidade de cada criança nesse estágio de desenvolvimento na educação infantil. A participação ativa dos estudantes, elemento central para que a inclusão em processo aconteça, precisa ser incentivada pelo/a professor/a na construção do protagonismo nas aulas e com reflexos em suas vidas, considerando estas peculiaridades. Como afirma Fonseca: 


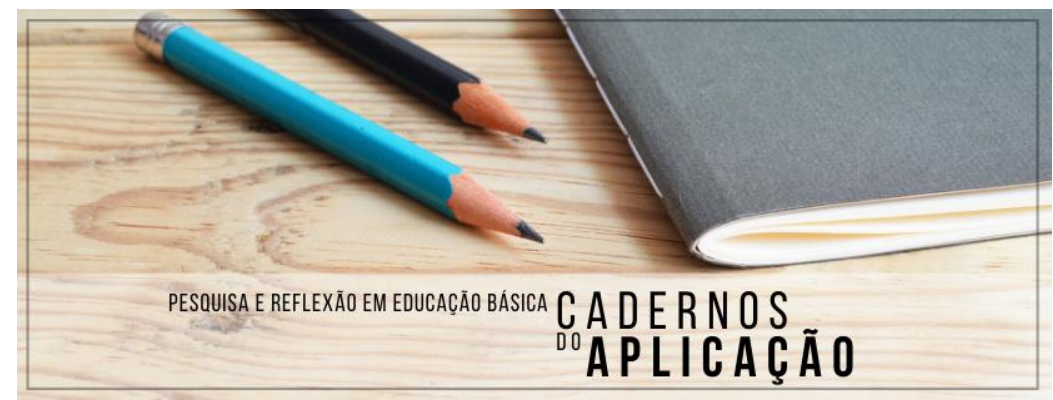

Cadernos do Aplicação

https://seer.ufrgs.br/CadernosdoAplicacao

Publicação Ahead of Print

ISSN 2595-4377 (online)

Porto Alegre | jul-dez. 2021 | v.34 | n.2

[...] não basta estar presente fisicamente em algum ambiente para que a participação seja efetiva. A participação é um ato político, participar ou não é uma opção pessoal, mas tem que ser permitido, dar as ferramentas e possibilidades para que as pessoas possam participar ativamente. (FONSECA, 2014, p.111)

O professor possui a responsabilidade de promover a participação de todos os estudantes e a mesma pode acontecer de diversas formas. Tendo como exemplo a atividade "meus pintinhos venham cá", comumente realizada na educação infantil, o professor de Educação Física possui diferentes possibilidades de desconstruir os estereótipos normalmente reforçados. A escolha da raposa não deve ser sempre pelos mais velozes e habilidosos da turma, quem for pego não precisa sair da atividade, a "mamãe pintinho" pode ser alternada com o "papai pintinho", o número de pegadores pode variar, entre outros. Ou seja, várias configurações podem ser propostas numa simples atividade para torná-la mais reflexiva e participativa, objetivando não estimular a competição exacerbada, valorizar somente os mais habilidosos e excluir os que de alguma forma não se encaixam em um formato padronizado de aula de Educação Física.

Considerando isso, o/a professor/a possui um papel que reverbera para além da sua prática docente e de forma alguma pode excluir os estudantes, seja por esquecimento, punição ou omissão. A escola tem um importante papel de incentivar a autonomia e protagonismo das crianças, por meio da ampla participação de todos/as, contemplando suas particularidades, desconstruindo os "esquecimentos" sociais e econômicos presentes na vida de tantos estudantes.

Um ponto importante a ser considerado é sobre a (não) parceria entre professora regente e professora de Educação Física. Durante o período da pesquisa, não foi observado nenhuma colaboração entre as mesmas para que as experiências e singularidades dos estudantes fossem potencializadas e suas dificuldades fossem contempladas. As trocas somente levavam em consideração as queixas, reclamações e mau comportamento da turma. Nesse sentido, Sayão (1996, p. 266) aponta que “o trabalho pedagógico não é fruto de iniciativas eminentemente individuais e sim, elemento do processo de discussão coletiva da unidade". 


\section{Considerações finais}

São notórias as transformações no campo do discurso na Educação Física escolar e o avanço das políticas de inclusão na educação. Porém, com olhar atento aos processos de inclusão e exclusão que ocorrem dentro da escola, podemos perceber que não é suficiente estar posto nas legislações e nem no referencial teórico o direito à participação, respeito e valorização das diferenças de toda e qualquer pessoa, apesar de reconhecermos a importância disso para embasar as ações. É preciso ampliar as discussões sobre as diferenças, dentro e fora do ambiente escolar, para que as ações diárias nas aulas sejam de fato transformadas e possibilite a participação de todos e todas.

Este artigo objetivou analisar as situações de ensino e seus processos de inclusão /exclusão observadas nas aulas de Educação Física na educação infantil numa escola pública na periferia da cidade do Rio de Janeiro. Não escolhemos um cenário óbvio para desenvolver essa pesquisa, posto que, nas turmas não tinha nenhuma criança com deficiência e gostaríamos de perceber e discutir outras formas pelas quais a exclusão se apresenta.

A dialética inclusão/exclusão nos escancara a complexidade de gerenciar esses processos na prática docente, conforme evidenciado na contradição entre o discurso e as ações da professora observada. Mesmo ela afirmando em sua entrevista que inclusão significa atender a todos os estudantes sem discriminação e adaptando as atividades para que eles participem de forma igualitária, em diversos momentos da sua prática isso não ocorreu. A exemplo desse fato, muitos docentes têm dificuldades em perceber as várias maneiras que a exclusão pode acontecer. Por isso, é importante compreender que é parte da tarefa docente promover o respeito entre os diferentes modos de ser e estar no mundo e se questionar a todo momento o que fazer para que sua aula não exclua qualquer pessoa.

É fundamental ressaltar que essa pesquisa é um estudo de caso, com o olhar voltado para uma realidade específica. Por isso, não temos o objetivo de generalizar para um contexto amplo, mas sim considerar, a título de reflexão, como a exclusão está presente nas aulas nos pequenos detalhes, como por exemplo, uma palavra dita, a escolha pouco pensada, uma atividade proposta, a festa temática não problematizada, entre outros, muitas vezes despercebidos por todo o corpo docente. 
Sendo assim, esses questionamentos não procuram responsabilizar somente o professor, pois reconhecemos que isso é um equívoco em todo o sistema envolvido. Isto é, compreende a própria sociedade que não questiona as diversas situações em que as culturas hegemônicas são valorizadas em detrimento das minorias, os inúmeros casos em que as mulheres são inferiorizadas em relação aos homens e o processo de ensino ligado somente ao estudante e ao professor, desprezando todos os envolvidos no processo.

As cinco categorias elencadas, competição, gênero, relações étnicos-raciais, violência e não participação, apresentam muitos entrelaçamentos e foram narradas situações de ensino em que se observou ações excludentes envolvendo os estudantes e a professora. Mesmo sendo na educação infantil, percebemos a grande influência de uma Educação Física ainda competitiva, voltada para o desempenho físico e o rendimento, e ainda que utilizando-se de elementos lúdicos e brincadeiras populares, a disputa entre meninos e meninas e a afirmação de vencedor/perdedor eram incentivadas.

Observamos ainda a não valorização da diversidade presente nos estudantes daquele contexto escolar e a invisibilidade de questões que emergiram nas aulas envolvendo gênero, raça e violência. A não participação dos estudantes nas atividades por ordem da professora em situações de impossibilidade material ou comportamental precisam ser repensadas pois desconsideram totalmente o cunho educacional e acolhedor que precisa estar presente na Educação Física e em todo ambiente escolar.

Como docentes, ao estarmos atentos em não reforçar opressões que possam acontecer nas aulas, fruto das experiências que muitos estudantes já trazem consigo, já estaremos desconstruindo, de alguma forma, essa complexa teia de exclusão e opressão, desde a educação infantil, de forma lúdica, potencializando o respeito com desdobramentos para a vida dessas crianças.

As situações discutidas evidenciam o quanto as questões inclusivas e excludentes que emergem em cada aula, precisam ser problematizadas para que os estudantes entendam o sentido da sua participação e o quanto é importante na construção da sua identidade como cidadão protagonista, já na educação infantil. A escola deve ser lugar de inclusão em que todas as diferenças sejam reconhecidas e valorizadas, sejam elas por etnia, gênero, classe social, religião, cultura, tipo físico, orientação sexual, estrutura familiar, entre outras, especialmente 


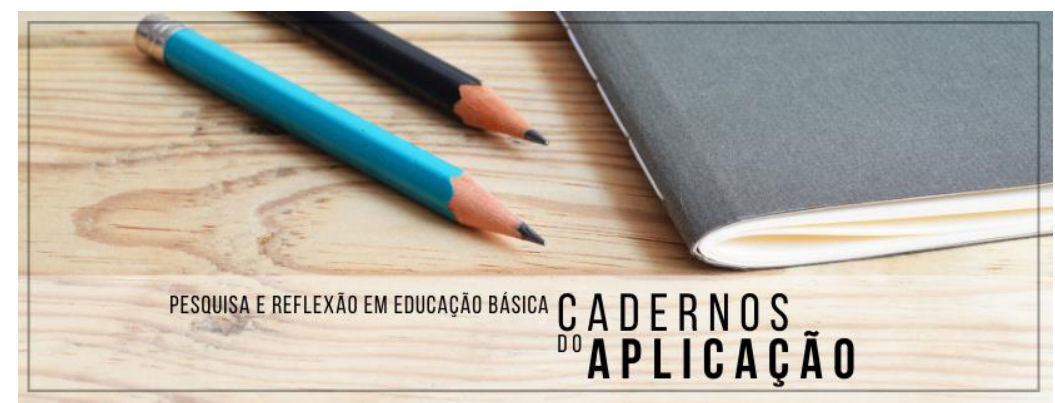

Cadernos do Aplicação https://seer.ufrgs.br/CadernosdoAplicacao

Publicação Ahead of Print

ISSN 2595-4377 (online)

Porto Alegre | jul-dez. 2021 | v.34 | n.2

na escola pública e gratuita, ratificando seu direito à educação de qualidade, crítica e democrática.

\section{Referências}

ASSIS, Lívia Carvalho de. Por uma Perspectiva Pedagógica para Intervenção da Educação Física com a Educação Infantil. 2015. Dissertação (Mestrado). Centro de Educação Física e Desporto. Universidade Federal do Espírito Santo, Vitória, 2015.

BARDIN, Laurence. Análise de Conteúdo. Lisboa: edições 70, 2016.

BOOTH, Tony; AINSCOW, Mel. Index Para a Inclusão. Desenvolvendo a aprendizagem e a participação na escola. Traduzido por: Mônica Pereira dos Santos. Produzido pelo LaPEADE, 2011.

BRASIL. Constituição da República Federativa do Brasil-artigo $6^{\circ}$. Brasília: 5 de outubro de 1988.

BRASIL. Lei de Diretrizes e Bases da educação nacional - $n .^{\circ} 9.394$. Brasília: 20 de dezembro de 1996.

BRASIL. Política Nacional de Educação Especial na Perspectiva da Educação Inclusiva. Ministério da Educação, Brasília, 2008.

BRASIL. Lei n. 13.146, de 6 de jul. de 2015. Lei Brasileira de Inclusão da Pessoa com Deficiência. Ministério da Educação, Brasília, 2015.

BRITO, Leandro Teófilo de; SANTOS, Mônica Pereira dos. Masculinidades na Educação Física escolar: um estudo sobre os processos de inclusão/exclusão. Revista Brasileira de Ciências do Esporte, vol.27, junho, p. 235-246, 2013.

CANDAU, Vera Maria; LUCINDA, Maria da Consolação; NASCIMENTO, Maria das Graças. Escola e Violência. Rio de Janeiro: DPA, 1999.

CHICON, José Francisco. Inclusão e Exclusão no Contexto da Educação Física Escolar. Movimento. Porto Alegre, v. 14, n. 01, p. 13-38, janeiro/abril de 2008.

COLETIVO DE AUTORES. Metodologia do ensino de Educação Física. São Paulo: Cortez, 1992.

FARIAS, Uirá de Siqueira; NOGUEIRA, Valdilene Aline; MALDONADO, Daniel Teixeira; RODRIGUES, Graciele Massoli; MIRANDA, M Maria Luiza de Jesus. Análise da produção do conhecimento sobre a Educação Física na Educação infantil. Movimento, Porto Alegre, v. 25, e25058, 2019. 


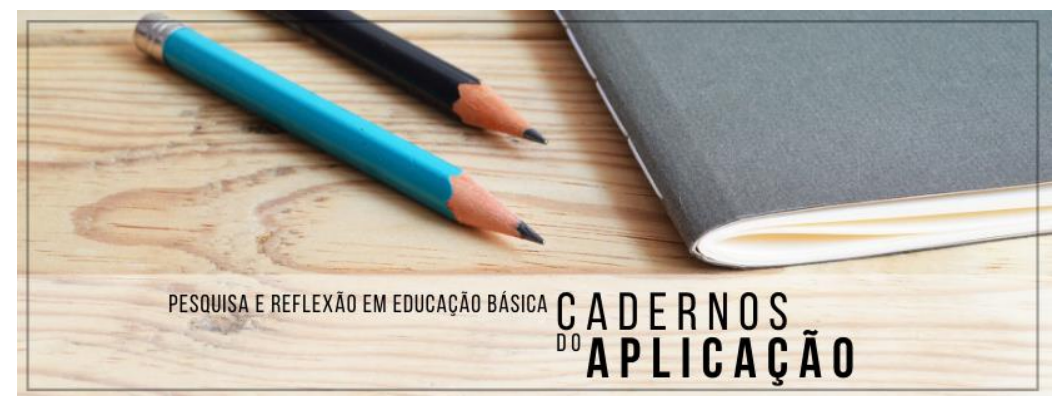

Cadernos do Aplicação https://seer.ufrgs.br/CadernosdoAplicacao

Publicação Ahead of Print

ISSN 2595-4377 (online)

Porto Alegre | jul-dez. 2021 | v.34 | n.2

FONSECA, João José Saraiva. Metodologia da pesquisa científica. Fortaleza: UEC, 2002.

FONSECA, Michele Pereira de Souza da. Formação de Professores de Educação Física e seus desdobramentos na perspectiva dos processos de inclusão/exclusão: reflexões sobre Brasil e Portugal. Rio de Janeiro, 2014. Tese (Doutorado em Educação). Faculdade de Educação, Universidade Federal do Rio de Janeiro, Rio de Janeiro, 2014.

FONSECA, Michele Pereira de Souza da; RAMOS, Maitê Mello Russo. Inclusão em movimento: discutindo a diversidade nas aulas de educação física escolar. In: PONTES JUNIOR, José Airton de Freitas (Org). Conhecimentos do professor de educação física escolar. Fortaleza, CE: EdUECE, p. 184-208, 2017.

FREIRE, Paulo. Pedagogia do oprimido. 17. ed. Rio de Janeiro, Paz e Terra, 1987.

FRICHE, Amélia Augusta de Lima.; ARAÚJO, Maria Rizoneide Negreiros de.; REIS, Nivânia Maria de Melo.; BONOLO, Palmira de Fátima. Uso terapêutico de tecnologias assistivas: direitos das pessoas com deficiência e ampliação da comunicação. Belo Horizonte, Brasil: Nescon/UFMG, 2015.

GERHARDT, Tatiana Engel; SILVEIRA, Denise Tolfo. Métodos de Pesquisa. Porto Alegre: Editora UFRGS, 2009.

GONÇALVES, Luiz Alberto Oliveira. Reflexão sobre a particularidade cultural na educação das crianças negras. Caderno de Pesquisa, São Paulo. N.63, nov. 1987.

IMBERNÓN, Francisco. Formação docente e profissional: formar-se para a mudança e a incerteza. 9. ed. São Paulo: Cortez, 2011.

LAKATOS, Eva Maria; MARCONI, Marina de Andrade. Fundamentos de Metodologia Científica. 5. ed. São Paulo: Atlas, 2003.

LERNER, Delia, Enseñar en la Diversidad. Conferencia dictada en las Primeras Jornadas de Educación Intercultural de la Provincia de Buenos Aires: Género, generaciones y etnicidades en los mapas escolares contemporáneos. Dirección de Modalidad de Educación Intercultural. La Plata, 28 de junio de 2007. Texto publicado en Lectura y Vida. Revista Latinoamericana de Lectura. Buenos Aires, v.26, n.4, dez. 2007.

LÜDORF, Silvia Maria Agatti. Metodologia da pesquisa do projeto à monografia. Rio de Janeiro: Shape, 2004.

SANTOS, José Vicente Tavares dos. A violência na escola conflitualidade social e ações civilizatórias. Educação e Pesquisa. São Paulo, v.27, n. 1, p. 105-122, jan/jun, 2001.

SANTOS, Mônica. Educação Inclusiva e a Declaração de Salamanca: Consequências ao Sistema Educacional Brasileiro. Integração - ano 10, n.22, p.34-40, 2000. 


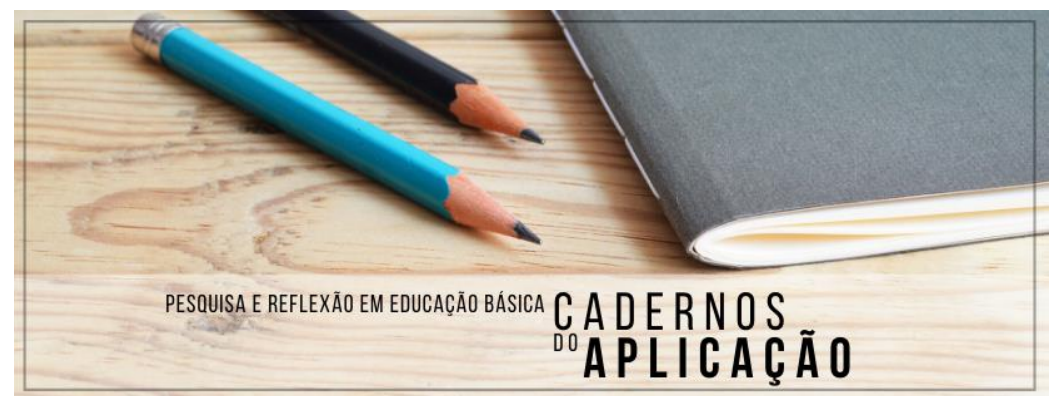

Cadernos do Aplicação https://seer.ufrgs.br/CadernosdoAplicacao

Publicação Ahead of Print

ISSN 2595-4377 (online)

Porto Alegre | jul-dez. 2021 | v.34 | n.2

SANTOS, Mônica; FONSECA, Michele; MELO, Sandra. Inclusão em Educação: diferentes interfaces. Curitiba, CRV, 2009.

SANTOS, Raquel Amorim dos; SILVA, Rosângela Maria de Nazaré Barbosa e. Racismo científico no Brasil: um retrato racial do Brasil. Educar em Revista, Curitiba, Brasil, v. 34, n. 68, p. 253-268, mar./abr. 2018.

SAVIANI, Demerval. Pedagogia histórico-crítica: primeiras aproximações. 11. ed. rev. Campinas, SP: Autores Associados, 2011.

SAWAIA, Bader (Org.). As artimanhas da Exclusão - análise psicossocial e ética da desigualdade social. Petrópolis: Vozes, 2017.

SAYÃO, Deborah Thome. Educação Física na Pré-escola: da especialização disciplinar à possibilidade de trabalho pedagógico integrado. Dissertação (Mestrado em Educação). Universidade Federal de Santa Catarina, 1996.

SAYÃO, Deborah Thome. Educação Física na pré-escola: principais influências teóricas. In: Anais do Congresso Brasileiro de Ciências do Esporte, 10. Goiânia: CBCE, p. 594-601, 1997.

SAYÃO, Deborah Thome. Educação Física na Educação infantil: riscos, conflitos e controvérsias. Revista Motrivivência. Florianópolis, ano XI, n. 13, p. 221-238, nov. 1999.

SAYÃO, Deborah Thome. Corpo e movimento: notas para problematizar algumas questões relacionadas à Educação infantil e a Educação Física. Revista Brasileira de Ciências do Esporte. Campinas, v. 23, n. 2, p. 55-67, jan. 2002.

SILVA, Ana Patrícia da. O princípio da Inclusão em Educação Física escolar: um estudo exploratório no município de São João Del Rei. Dissertação de Mestrado: Universidade Federal do Rio de Janeiro, 2004.

SOUSA, Eustáquia Salvadora de; ALTMANN, Helena. Meninos e meninas: expectativas corporais e implicações na educação física escolar. Cad. CEDES. vol.19, n.48, p.52-68, 1999.

TARDIF, Maurice. Saberes docentes e formação profissional. 9. ed. Petrópolis: Vozes, 2008.

UNESCO. Declaração de Salamanca. Necessidades Educativas Especiais - NEE In: Conferência Mundial sobre NEE. Salamanca, Espanha: UNESCO, 1994.

UNESCO. Declaração Mundial sobre Educação para Todos: Satisfação das Necessidades Básicas de Aprendizagem, Jomtien, Tailândia: UNESCO, 1990.

Data de submissão: 09/01/2021

Data de aceite: 20/03/2021

DOI: https://doi.org/10.22456/2595-4377.110542 